\title{
Sedative, hypothermic, anxiolytic effects and rapid radical scavenging property of aqueous leaf extract of Vitex doniana (Lamiaceae) in mice
}

\section{Joshua Oloruntobi IMORU ${ }^{1 *}$, Ayodeji Oluwabunmi ORIOLA ${ }^{2}$, Idris Ajayi OYEMITAN ${ }^{1}$ and Moses Atanda AKANMU ${ }^{1}$}

${ }^{1}$ Department of Pharmacology, Faculty of Pharmacy, Obafemi Awolowo University, lle-Ife, Osun State, Nigeria. ${ }^{2}$ Drug Research and Production Unit, Faculty of Pharmacy, Obafemi Awolowo University, Ile-Ife, Osun State, Nigeria

\section{ABSTRACT}

Vitex doniana is used ethnomedicinally for the management of madness, insanity, and epilepsy. This study was undertaken to evaluate the sedative, hypothermic and anxiolytic effects of crude aqueous leaf extract of Vitex doniana (AVD) in mice, as well as its rapid radical scavenging property. Doses of 250,500, and 1000 $\mathrm{mg} / \mathrm{kg}$ AVD were adopted for the pharmacological testing in mice of both sexes $(n=6)$. The behavioural effects of the extract in the open field apparatus were determined. AVD was evaluated for its anxiolytic effect, using elevated T- maze, staircase, and holeboard models. While the sedative and hypothermic effects of the extract in mice were determined by assessments of ketamineinduced sleeping time and rectal temperature respectively. AVD was subjected to rapid radical scavenging test using thinlayer chromatography (TLC)-bioautography. The results showed AVD to have an inhibitory effect on CNS in the open field test. AVD demonstrated anxiolytic effect at $250 \mathrm{mg} / \mathrm{kg}$, and sedative effect at 500 and $1000 \mathrm{mg} / \mathrm{kg}$. The sedative effect of AVD at 500 and $1000 \mathrm{mg} / \mathrm{kg}$ was further revealed in ketamine-induced sleeping time and rectal temperature. AVD also showed strong free radical scavenging property attributed to the presence of fatty acid esters, terpenes, phenolics, and phenolic glycosides. AVD is acutely non-toxic and it possesses significant sedative, hypothermic and anxiolytic effects, which could in part be due to the presence of rapid free radical scavenging compounds, thus, providing pharmacological justification for its ethnomedicinal uses as a curative for madness and insanity.

Keywords: Vitex doniana; sedative; anxiolytic; hypothermic; rapid radical scavenging property.
*Correspondence to Author: Joshua Oloruntobi IMORU

Department of Pharmacology, Faculty of Pharmacy, Obafemi Awolowo University, Ile-Ife, Osun State, Nigeria

How to cite this article:

Joshua Oloruntobi IMORU, Ayodeji Oluwabunmi ORIOLA, Idris Ajayi OYEMITAN, Moses Atanda AKANMU.Sedative, hypothermic, anxiolytic effects and rapid radical scavenging property of aqueous leaf extract of Vitex doniana (Lamiaceae) in mice. International Journal of Traditional and Complementary Medicine 2020, $5: 32$

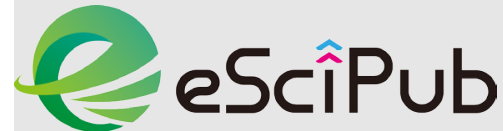

eSciPub LLC, Houston, TX USA. Website: https://escipub.com/ 


\section{Introduction}

Vitex doniana (Synonyms: Vitex cuneata Schumach \& Thonn, Vitex cienkowskii kotschy \& peyr., Vitex pachyphylla Baker; Family: Verbenaceae) is a medium-sized deciduous and semievergreen tree measuring 8-18 meters high, and with a heavily rounded crown and a clear pole up to 5 meters. It has a rough, pale brown or gray bark with fine fissures running down the trunk, and with bases of the old trees having oblong scale. The leaves are arranged like the fingers of a hand (palmate) and have five leathery leaflets, with the middle leaflet being the largest. The tips of the leaf are rounded or emarginate, while the bases are cuneate. The leaf is dark green above, pale greyish to green below, thickly leathery, and with a few or no scattered stellate hairs on the upper surface. The petals of the flower are white, with the exception on the largest lobe, which is purple, and in dense opposite and axillary cymes. The flowers are small, blue or violet, and are 3 to $12 \mathrm{~cm}$ in diameter, with only a few open at a time. Vitex doniana fruit is oblong and about $3 \mathrm{~cm}$ long. The fruit is green when young, but turns purplish-black on ripening and with a starchy black pulp. The fruit contains one hard conical seed. The seed is 1.5 to $2 \mathrm{~cm}$ long, and 1 to $1.2 \mathrm{~cm}$ wide [1].

Vitex doniana has copious ethnomedicinal uses. Leaf sap is used as an eye drop to treat conjunctivitis and other eye complaints. The leaf decoction is smeared externally as a galactagogue and against headache, stiffness, measles, rash, fever, chickenpox and hemiplegia, and internally as a tonic, anodyne and febrifuge, and to treat respiratory diseases. The pastes of pounded leaves and bark are applied to wounds and burns. A root decoction is administered orally to treat ankylostomiasis, rachitis, gastro-intestinal disorders and jaundice, and as an anodyne. The powdered bark added to water is taken to treat colic, and a bark extract is used to treat stomach complaints and kidney troubles. The bark is also used against leprosy and liver diseases, and to control bleeding after childbirth. Dried and fresh fruits are eaten against diarrhoea, and as a remedy against lack of vitamin $A$ and $B$. The twigs are used as chewing sticks for teeth cleaning [2]. The hot aqueous extract of $V$. doniana leaves is used for the treatment of stomach and rheumatic pains, inflammatory disorders, diarrhoea and dysentery. The root has been used to treat epilepsy, nausea, and colic [3]. The stem bark extract of the tree is used for the control of hypertension, treatment of stomachache, pains, disorders, indigestion and sterility [4]. Vitex doniana like Vitex rivularis is said to have been used ethnomedically to cure madness, insanity and epilepsy ${ }^{[5,6]}$.

Vitex doniana is said to contain vitamins $A, B 1$, $\mathrm{B} 2, \mathrm{~B} 6$, and $\mathrm{C}^{[7]}$. The fruit juice has a $\mathrm{pH}$ of about 4.5. Per $100 \mathrm{~g}$ edible portion, the composition of the fruit pulp is water $59.5-73.5 \mathrm{~g}$, energy $435 \mathrm{~kJ}$ (104 kcal), protein $0.6-0.8 \mathrm{~g}$, fat $0.1-1.3 \mathrm{~g}$, carbohydrate $27.5 \mathrm{~g}$, fibre $1.3 \mathrm{~g}$, Ca $20-47 \mathrm{mg}, \mathrm{P} 47$ $\mathrm{mg}$, Fe 2.0-4.5 mg, K $15.70 \mathrm{mg}$, Na $10.40 \mathrm{mg}$, Cu $2.70 \mathrm{mg}$ ascorbic acid 6-18 $\mathrm{mg}{ }^{[8]}$.

The phytochemical screening of the various parts of the plant extract showed the presence of saponins, tannins, phenols, cardiac glycosides, flavonoids, sterols, and triterpenes. Ethyl acetate cold extract of $V$. doniana showed the presence of alkaloids, flavonoids, cardiac glycosides and steroids, but the absence of saponins [9]. In another screening, saponins were found in large concentration in ethanol, acetone, and hot aqueous leaf extracts of $V$. doniana, but absence in methanol, and cold aqueous extracts of $V$. doniana [10]. The aqueous bark extract of $V$. doniana was said to have only flavonoids present. Ethanol bark extract showed the presence of tannins, flavonoids, glycosides, steroids, and proteins, but the absence of saponins, alkaloids and phenols. Acetone bark extract showed tannins, saponins, flavonoids, glycosides, steroids, and proteins, with the absence of alkaloids and phenols. The aqueous root extract contained only tannins. Ethanol root extract, like acetone bark extract, contained others except for alkaloids and phenols. While acetone root extract had tannins, saponins, glycosides, steroids, proteins, but lacked flavonoids, alkaloids, and 
phenols [11]. The phytochemical composition of $V$. doniana fruit pulp revealed the presence of flavonoids, and alkaloids, while phenols and tannins were moderately present, steroids, saponins, reducing sugar, terpenoids, and cardiac glycosides were abundantly present ${ }^{[12] .}$

Toxicology results on the leaf extract of $V$. doniana, most especially through the oral route, have shown no clinical signs of toxicity or adverse toxicological effects in treated laboratory animals ${ }^{[9]}$. However, the bark stem of $V$. doniana has been reported to be moderately toxic via intraperitoneal administration ${ }^{[13] .}$

The leaf extract of $V$. doniana has been found to have anti-inflammatory and analgesic effects. [14]. The aqueous leaf extract of $V$. doniana has also shown the antioxidant property ${ }^{[15]}$. The stem bark extract of $V$. doniana has been found to have a marked dose-dependent hypotensive activity in both normotensive and hypertensive rats. Extracts from the stem bark have also shown a different level of in vitro trypanocidal activity against Trypanosoma brucei ${ }^{[16]}$. Other reported pharmacological activities of $V$. doniana include hypolipidaemic effects [17], hypolipidaemic and antidiabetic effects ${ }^{[18]}$.

Many are disorders and diseases of the nervous system which include: Parkinson's disease, Alzheimer's disease, Multiple Sclerosis, Epilepsy, Anxiety, Insomnia, Depression, psychoses e.t.c. [19]. Anxiety, defined as an unpleasant effect characterized by tense and physically exhaustive alertness focused on an impending and inevitable thought, not an objectively apparent danger or emergency (doomsday syndrome), along with a painful awareness of being powerless to do anything about the situation, was reported to be affecting about one-eighth of the world ${ }^{[20]}$.

Novel drugs with fewer side effects and better tolerability in managing mental disorders are needed. Vitex doniana (Sweet) leaf is used ethnomedically to treat mental disorders and epilepsy. However, there is the paucity of information on the neuropsychopharmacology profile substantiating the uses of this plant, hence this study.

\section{Materials and methods}

\subsection{Plant material}

Vitex doniana Sweet was collected in March 2018 at Kajola-Akile community, Ede road, IleIfe, Osun State, Nigeria with the longitude 4.478305 and latitude 7.505034 (Provider; GPS, Accuracy; 9.868601, Speed; 0.407223). The botanical identity was done by Mr I.I. Ogunlowo, the Curator in the Department of Pharmacognosy, Faculty of Pharmacy, Obafemi Awolowo University (O.A.U.), Ile-Ife. Herbarium specimens were deposited at Faculty of Pharmacy Herbarium, and at Ife Herbarium, Department of Botany, both in O.A.U., Ile-Ife with Voucher Numbers IFE 17732 and FPI 2174 respectively. The plant name has been checked with http://www.theplantlist.org. This name is the accepted name of a species in the genus $\mathrm{Vi}$ tex (family Lamiaceae). The record derives from WCSP (data supplied on 2012-03-23) which reports it as an accepted name (record 213428) with original publication details: Hort. Brit. 323 1826. Fresh leaves of V. doniana were collected, air-dried and milled into a powder.

\subsection{Animals}

The animals used for this study were adult mice $(18-25 \mathrm{~g})$ of both sexes. All the animals were bred and housed in a well-lit and aerated room in the Animal House, Faculty of Pharmacy, Obafemi Awolowo University, lle - Ife. They were maintained under natural daylight/night condition. All animals had free access to water and standard commercial diet (Vital Feed ${ }^{\circledR}$ brand, produced by Grand Cereals Limited, a subsidiary of UAC Nigeria PLC). The experiments were carried out between 9.00 am and $3.00 \mathrm{pm}$. The animals fasted overnight before the experiments. They were used in groups of six per dose level of the crude extract, positive and negative controls. Each mouse was used only once. The research was conducted under the internationally accepted principles for laboratory animal use and care as found for example in the IJTCM: https://escipub.com/international-journal-of-traditional-and-complementary-medicine/ 
European community guidelines (EEC Directive of 1986; 86/609/EEC). All experiments were examined and approved by the Faculty of Pharmacy board committee and Postgraduate board committee of Obafemi Awolowo, University lleIfe, Nigeria

\subsection{Laboratory materials}

Observation cage, elevated T-maze, hole-board apparatus, Ugo Basile electroconvulsive machine (Model 57800, Ugo Basile Biological Research Apparatus, Italy), stopwatch, manual counter, syringes and needles, weighing balance and a digital thermometer.

\subsection{Drugs and chemicals}

Diazepam (Roche, Basel, Switzerland), 2,2-diphenyl-1-picrylhydrazyl (DPPH) radical (Sigma Chemicals Co, St. Louis, Missouri, U.S.A.), ketamine (Rotex Medica), and normal saline (Unique Pharmaceutical Limited, Lagos, Nigeria). The crude extract was dissolved in the required volume of normal saline. The drugs and crude extract were freshly prepared on each day of the experiments.

\subsection{Preparation of plant extract}

Powdered leaves of $V$. doniana $(500 \mathrm{~g}$ ) were extracted in $2.5 \mathrm{~L}$ of distilled water for 48 hours with constant agitation on a mechanical shaker. The menstruum was filtered from the marc, concentrated in vacuo at $50^{\circ} \mathrm{C}$ on a rotary evaporator, and freeze-dried to obtain a $69.90 \mathrm{~g}$ crude aqueous extract ( $13.98 \% w / w$ yield). The extract was then stored in the refrigerator before its use.

\subsection{Pharmacological studies}

\subsubsection{Acute toxicity test}

The method of Lorke ${ }^{[21]}$ was used. This involves using the 13-animal model for rapid determination of $L D_{50}$. The $1^{\text {st }}$ phase uses 3 animals for each dose level 10,100 and $1000 \mathrm{mg} / \mathrm{kg}$. The mice were kept under the same laboratory conditions and observed for signs of toxicity which include but not limited to paw-licking, stretching, respiratory distress and mortality for the first critical four hours and after 24 hours the number of deaths per group was recorded. The result obtained from this test was used as a basis for selecting the subsequent doses in the $2^{\text {nd }}$ phase following a standard table. The $2^{\text {nd }}$ phase involved administering four different doses to one mouse per group and the mice are observed for signs of toxicity for the first critical four hours and thereafter 24 hours for mortality. The median lethal dose $\left(\mathrm{LD}_{50}\right)$ was calculated as the geometric mean of doses that caused 0 and $100 \%$ mortality respectively. The $L D_{50}=\sqrt{ }(A \times B)$, where $A=$ maximum dose that caused $0 \%$ mortality and $B$ $=$ minimum dose that caused $100 \%$ mortality.

\subsubsection{Neuropharmacological studies}

The working doses (i.e. treatment doses) used in the study were arrived at by the formula $1 / 2 x$ $L D_{50}$. All treatment doses were below half of the $\mathrm{LD}_{50}$

2.6.2.1 Assessment of the effect of $V$. doniana extract on rearing, locomotion and grooming in the open field apparatus

The observation cage was used in this assessment. Thirty male mice were randomly distributed into five groups ( $n=6)$. Group (1) was given normal saline $(10 \mathrm{ml} / \mathrm{kg}$, p.o.) which served as the vehicle (negative control), groups (2-4) were given the crude extract (250, 500 and 1000 $\mathrm{mg} / \mathrm{kg}$, p.o.), while group (5) was given diazepam (5 mg/kg, p.o.) which served as reference drug. All animals were observed and scored singly in the cage. Rearing and grooming were scored for 30 minutes while line crossing was scored for the first 10 minutes of the 30 minutes duration. Rearing (vertical locomotion) is defined as the lifting of the forelimbs off the floor completely [22], while line crossing was counted when the animal crossed a line with all the limbs. Grooming was taken as the number of body cleaning with paws, of the body and pubis with the mouth, and face washing ${ }^{[23]}$. Each animal was used only once and the floor of the cage cleaned with $100 \%$ methanol after each assessment to remove olfactory cue from one animal to the other ${ }^{[24]}$. The animals used were fasted overnight but allowed free access to water. All assessments were carried out between 09:00 and 17:00 $\mathrm{h}^{[25]}$. 


\subsubsection{Assessment of the effect of $V$. doniana extract on anxiety on the elevated $T$ - maze}

Thirty adult mice were randomly distributed into five groups $(n=6)$. Group (1) was given vehicle (normal saline; $10 \mathrm{ml} / \mathrm{kg}$, p.o.), groups (2-4) were given the crude extracts $(250,500$ and 1000 $\mathrm{mg} / \mathrm{kg}$, p.o.), while group (5) was given the reference drug (diazepam; $2 \mathrm{mg} / \mathrm{kg}$, p.o.). Sixty minutes after the administration of the vehicle, extract, and reference drug, each animal was scored singly; for the inhibitory avoidance task (in the closed arm), the animal was placed at the end of the closed arm and the latency to withdraw from this arm with the four paws was recorded in three successive trials made at $30 \mathrm{sec}-$ onds intervals. While for the one-way escape task which initiated 30 seconds after the completion of the avoidance tasks, the animal was placed at the end of one of the open arms and withdrawal latency from this arm was similarly recorded with a stopwatch ${ }^{[26]}$.

2.6.2.3 Assessment of the effect of $V$. doniana extract on anxiety on the staircase model

Mice of both sexes were used in this model. The staircase test was carried out by the method described by $[27,28]$. The staircase was made of wood and consisted of five identical steps $2.5 \mathrm{~cm}$ high, $10 \mathrm{~cm}$ wide, $7.5 \mathrm{~cm}$ deep surrounded by walls, the height of which $(10 \mathrm{~cm})$ was constant along the whole length of the staircase. A wooden box $(15 \times 10 \times 10 \mathrm{~cm})$ with one side open was placed facing the staircase. The mouse was gently placed on the floor of the box with its back to the staircase. During a 5 min period, the number of steps climbed and the number of rearing made were recorded. A step was considered climbed when all four paws were placed on the step. Mice were divided into five groups. Group (1) was given normal saline (10 $\mathrm{ml} / \mathrm{kg}$, p.o.) which served as the vehicle (negative control), groups (2-4) were given the crude extract (250, 500 and $1000 \mathrm{mg} / \mathrm{kg}$, p.o.), while group (5) was given diazepam (2 mg/kg, p.o.) which served as the reference drug ${ }^{[28]}$. Thirty or sixty minutes after treatment, the number of steps climbed and the rearing responses were recorded for each mouse for 5 minutes. The staircase was wiped with $70 \%$ methanol and allowed to dry between tests to remove any olfactory cues which might modify the behaviour of the next animal [29].

\subsubsection{Assessment of the effect of $V$. doniana extract on anxiety on the hole-board}

The hole-board apparatus was used in this assessment. Thirty male mice were randomly allotted into five groups $(n=6)$. Group (1) was given normal saline (10 ml/kg, p.o.) which served as the vehicle (negative control), groups (2-4) were given the crude extracts $(250,500$ and 1000 $\mathrm{mg} / \mathrm{kg}$, p.o.), while group (5) was given diazepam (2 mg/kg, p.o.) which served as reference drug. Thirty and sixty minutes after the administration of reference drug and extract respectively, the animals were placed directly from their home cages to the hole-board apparatus and allowed to freely explore for 5 minutes. After each observation, the hole-board apparatus was cleaned with $100 \%$ methanol to remove scent cue left from the preceding animal. The head-dip was scored using a manual counter [30].

\subsubsection{Assessment of the $V$. doniana extract on ketamine-induced sleeping time in mice}

The method described for screening intravenous anaesthetics was used with minor modification [31]. Two important parameters are normally evaluated. The first is the loss of righting reflex confirmed when the animal, placed on its back fails to recover from this position within 60 seconds. The second parameter includes onset and duration of loss of righting reflex (in second or minutes). The onset (latency to sleep) is defined as the period from injection to the time of loss of righting reflex, while the duration (total sleeping time or total time of loss of righting reflex) is the period when the animal remained un-stimulated or does not respond to stimuli (shown by the inability to move its head of body). The total sleeping time in this study is taken as the time of loss of consciousness (loss of righting reflex) and

IJTCM: https://escipub.com/international-journal-of-traditional-and-complementary-medicine/ 5 
recovery of righting reflex. Recovery is considered to have occurred when the animal after spontaneous righting, would re-right itself within 15 seconds when placed on its back ${ }^{[31,32]}$. Thirty adult mice were randomly distributed into five groups $(n=6)$. Group (1) was given normal saline (10 $\mathrm{ml} / \mathrm{kg}$, p.o.) which served as the vehicle (negative control), groups (2-4) were given the crude extracts $(250,500$ and $1000 \mathrm{mg} / \mathrm{kg}$, p.o.), while group (5) was given diazepam (5 mg/kg, p.o.) which served as reference drug. Sixty minutes after the administration of vehicle, extract and reference drug, animals were administered $100 \mathrm{mg} / \mathrm{kg}$ of ketamine ${ }^{[33]}$. The latency period and total sleeping time were noted and recorded for each mouse as described above.

\subsubsection{Assessment of the effect of $V$. doniana extract on the rectal temperature in mice}

Five groups of mice $(n=6)$ were randomly selected. Group (1) was given normal saline (10 $\mathrm{ml} / \mathrm{kg}, \mathrm{p}$.o.) which served as the vehicle (negative control), groups (2-4) were given the crude extracts (250, 500 and $1000 \mathrm{mg} / \mathrm{kg}$, p.o.), while group (5) was given diazepam ( $5 \mathrm{mg} / \mathrm{kg}$, p.o.) which served as reference drug. The rectal temperature of each mouse in all the groups were taken with a digital thermometer (Thermo probe) by inserting the probe $2 \mathrm{~cm}$ deep into the anus of the mice shortly before treatment time and at $30,60,90$ and 120 minutes after treatment. The test was done between 10:00 and 14:00 $\mathrm{h}$ [33]. The mean \pm SEM was then calculated for each group [35-38].

\subsubsection{7}

\section{Rapid radical scavenging test}

The rapid free radical scavenging test otherwise known as thin-layer chromatography (TLC)-bioautography was carried out according to the methods of Burits and Bucar [39] and Mensor et al. ${ }^{400}$. Here, an aliquot of the extract was dissolved in $50 \%$ aqueous methanol. This was spotted on a normal phase TLC plate (Silica gel $\left.F_{254 n m}\right)$. The plate was developed using a trinary solvent system of $n$-butanol - acetic acid - distilled water (80:15:5) in duplicate. The chromatograms were sprayed with $10 \mathrm{mg} / \mathrm{mL}$ solution of a stable 2,2-diphenyl-1-picrylhydrazyl (DPPH) free radical in methanol. The appearance of yellow spots against purple DPPH background indicated free radical scavenging property. Those spots on the TLC chromatograms which bleached the purple DPPH solution immediately were recorded as strongly free radical scavengers. The time taken for the scavenging action was also noted.

\subsection{Statistical analysis}

Results were expressed as mean \pm S.E.M. Statistical comparisons were performed by one-way ANOVA followed by Student Newman-Keuls test using Graph Pad Prism version 3.0, USA. $P<$ 0.05 was considered significant.

\section{RESULTS}

\subsection{Acute toxicity test ( $\left.L D_{50}\right)$}

The result of the oral acute toxicity test $\left(L D_{50}\right)$ of the aqueous leaf extract of Vitex doniana (AVD) was $\geq 5000 \mathrm{mg} / \mathrm{kg}$. The result is showed in Table 1.

\subsection{Effect of oral administration of $V$. do- niana on locomotion activity in mice}

The results obtained showed that the aqueous leaf extract of $V$. doniana at the doses used 250, 500 and $1000 \mathrm{mg} / \mathrm{kg}$, p.o. and standard drug diazepam (5 mg/kg, p.o.), significantly $\left[\mathrm{F}_{4,25}=\right.$ 130.95, $\mathrm{P}<0.05$ ] reduced locomotion activity compared to the vehicle-treated group in novelty-induced locomotion behavioural study in mice. The result is presented in Figure 1a.

\subsubsection{Effect of oral administration of $V$. do- niana on rearing activity in mice}

The results obtained showed that the aqueous leaf extract of $V$. doniana at the doses used 250, 500 and $1000 \mathrm{mg} / \mathrm{kg}$, p.o. and standard drug diazepam (5 mg/kg, p.o.), significantly $\left[F_{4,25}=\right.$ 98.94, $\mathrm{P}<0.05$ ] reduced rearing activity compared to the vehicle-treated group in novelty-induced rearing behavioural study in mice. The result is presented in Figure 1b.

\subsubsection{Effect of oral administration of $V$. do- niana on grooming activity in mice}

The results obtained showed that the aqueous leaf extract of $V$. doniana at the doses used 250, 
500 and $1000 \mathrm{mg} / \mathrm{kg}$, p.o. and standard drug di- compared to the vehicle-treated group in novazepam $\left(5 \mathrm{mg} / \mathrm{kg}\right.$, p.o.), significantly $\left[\mathrm{F}_{4,25}=\right.$ elty-induced grooming behavioural study in 23.78, $\mathrm{P}<0.05]$ reduced grooming activity mice. The result is presented in Figure 1c.

TABLE 1: LD $_{50}$ Determination of Vitex doniana aqueous leaf extract in mice

\begin{tabular}{|c|c|c|c|}
\hline \multicolumn{4}{|l|}{ Oral } \\
\hline \multicolumn{4}{|l|}{ First phase } \\
\hline $\begin{array}{l}\text { Dose of aqueous leaf extract of } \\
\text { Vitex doniana }(\mathrm{mg} / \mathrm{kg}, \text { p.o.) }\end{array}$ & $\begin{array}{l}\text { No of mice } \\
\text { used }\end{array}$ & No of animals that died & Mortality rate \\
\hline 10 & 3 & 0 & $0 / 3$ \\
\hline 100 & 3 & 0 & $0 / 3$ \\
\hline 1000 & 3 & 0 & $0 / 3$ \\
\hline \multicolumn{4}{|l|}{ Second phase } \\
\hline 1,600 & 1 & 0 & $0 / 1$ \\
\hline 2,900 & 1 & 0 & $0 / 1$ \\
\hline 5,000 & 1 & 0 & $0 / 1$ \\
\hline
\end{tabular}

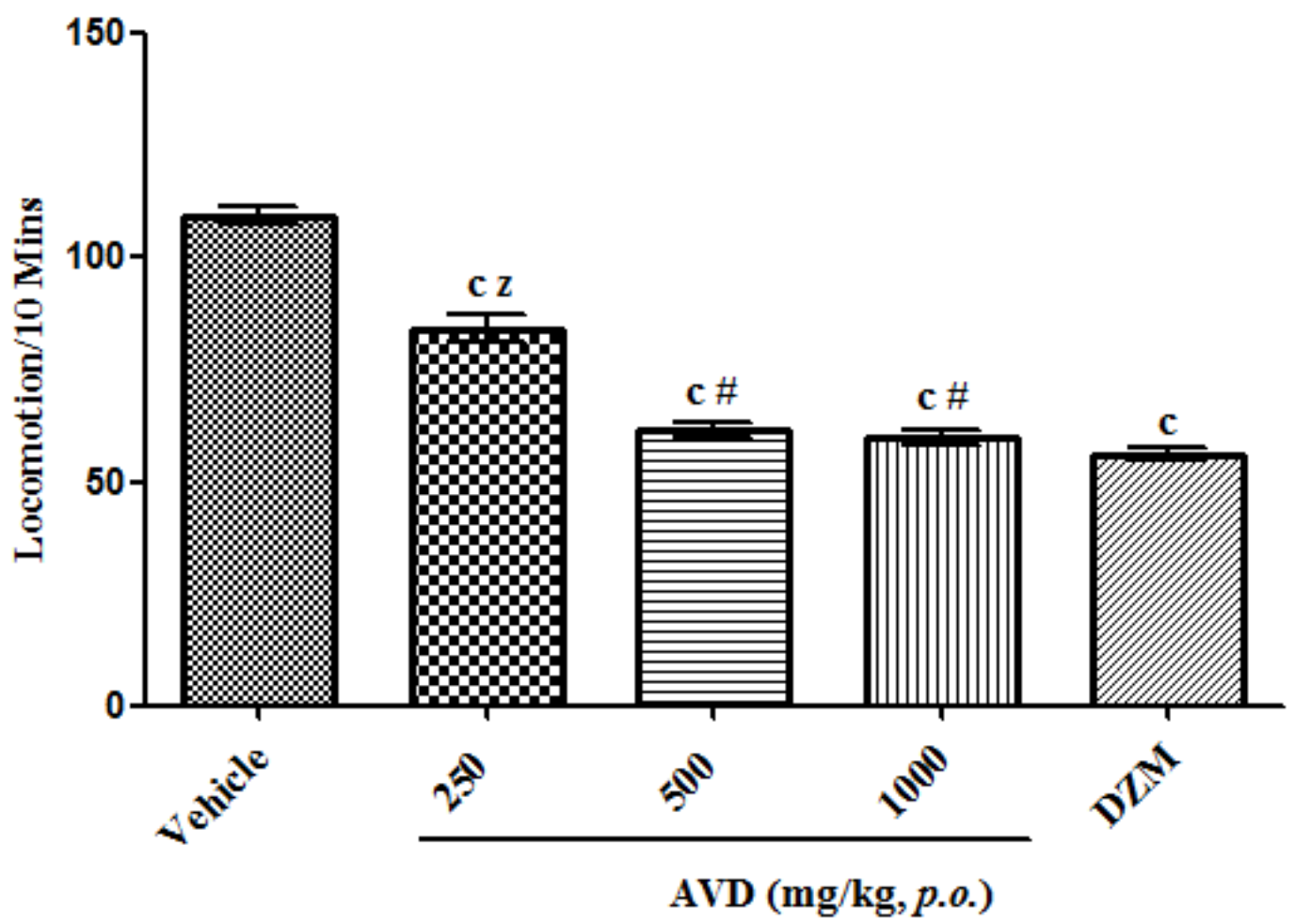

Figure 1a: Effect of aqueous leaf extract of Vitex doniana (AVD) on locomotion in mice. Each bar is expressed as Mean \pm SEM; $(n=6)$. $c=P<0.05$ compared to vehicle (Normal saline; $10 \mathrm{ml} / \mathrm{kg}$, p.o.), $\mathrm{Z}=\mathrm{P}<0.05$ compared to positive control (Diazepam (DZM); $5 \mathrm{mg} / \mathrm{kg}$, p.o.) and \# $=\mathrm{P}<0.05$ compared $250 \mathrm{mg} / \mathrm{kg}$ to $500 \mathrm{mg} / \mathrm{kg}$ and $1000 \mathrm{mg} / \mathrm{kg}$; (ANOVA;SNK). 


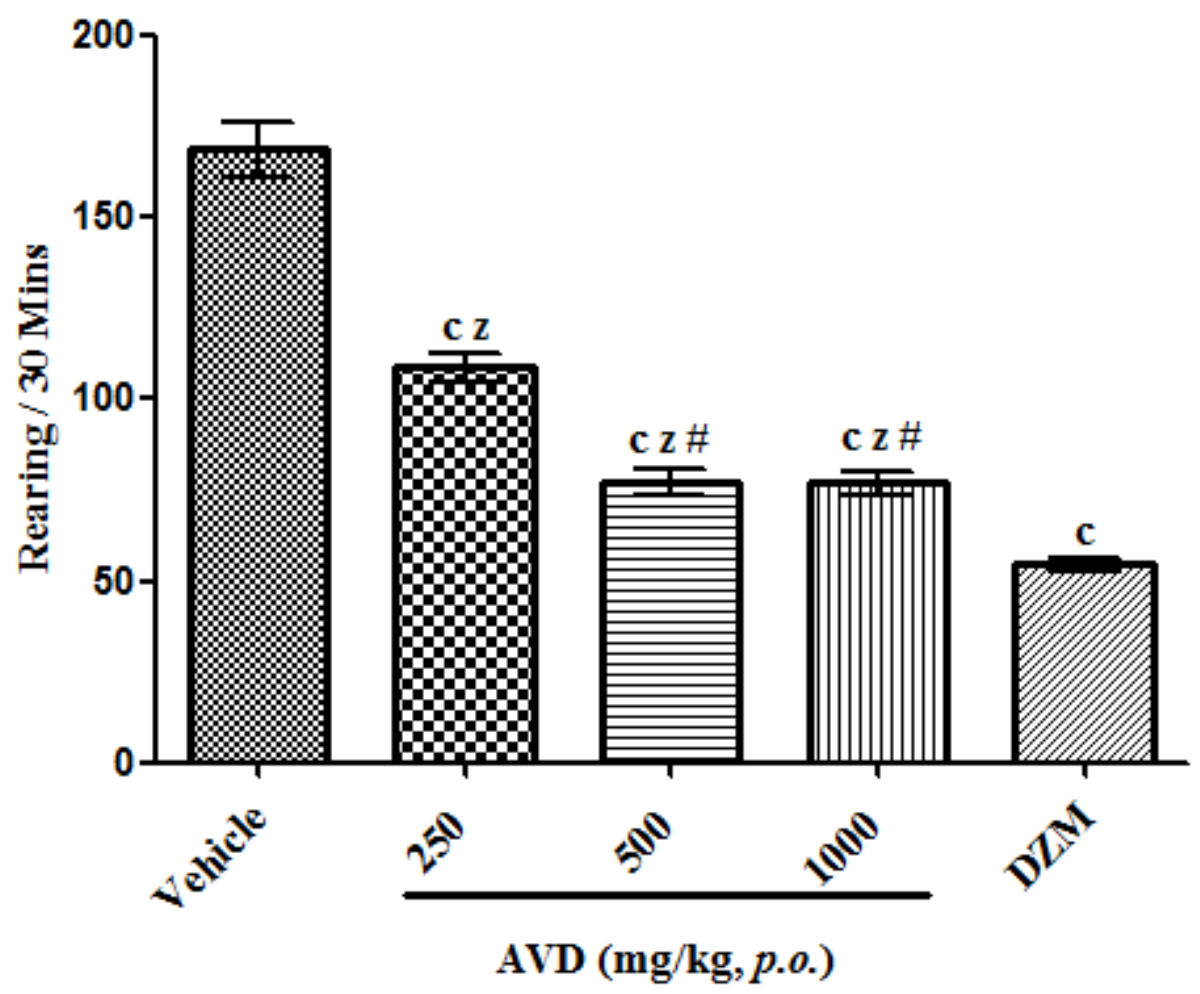

Figure 1b: Effect of aqueous leaf extract of Vitex doniana (AVD) on rearing in mice. Each bar is expressed as Mean \pm SEM; $(n=6) . c=P<0.05$ compared to vehicle (Normal saline; $10 \mathrm{ml} / \mathrm{kg}$, p.o.), $\mathrm{z}=\mathrm{P}<0.05$ compared to positive control (diazepam (DZM); $5 \mathrm{mg} / \mathrm{kg}$, p.o.) and \# $=\mathrm{P}<0.05$ compared $250 \mathrm{mg} / \mathrm{kg}$ to $500 \mathrm{mg} / \mathrm{kg}$ and $1000 \mathrm{mg} / \mathrm{kg}$; (ANOVA; SNK).

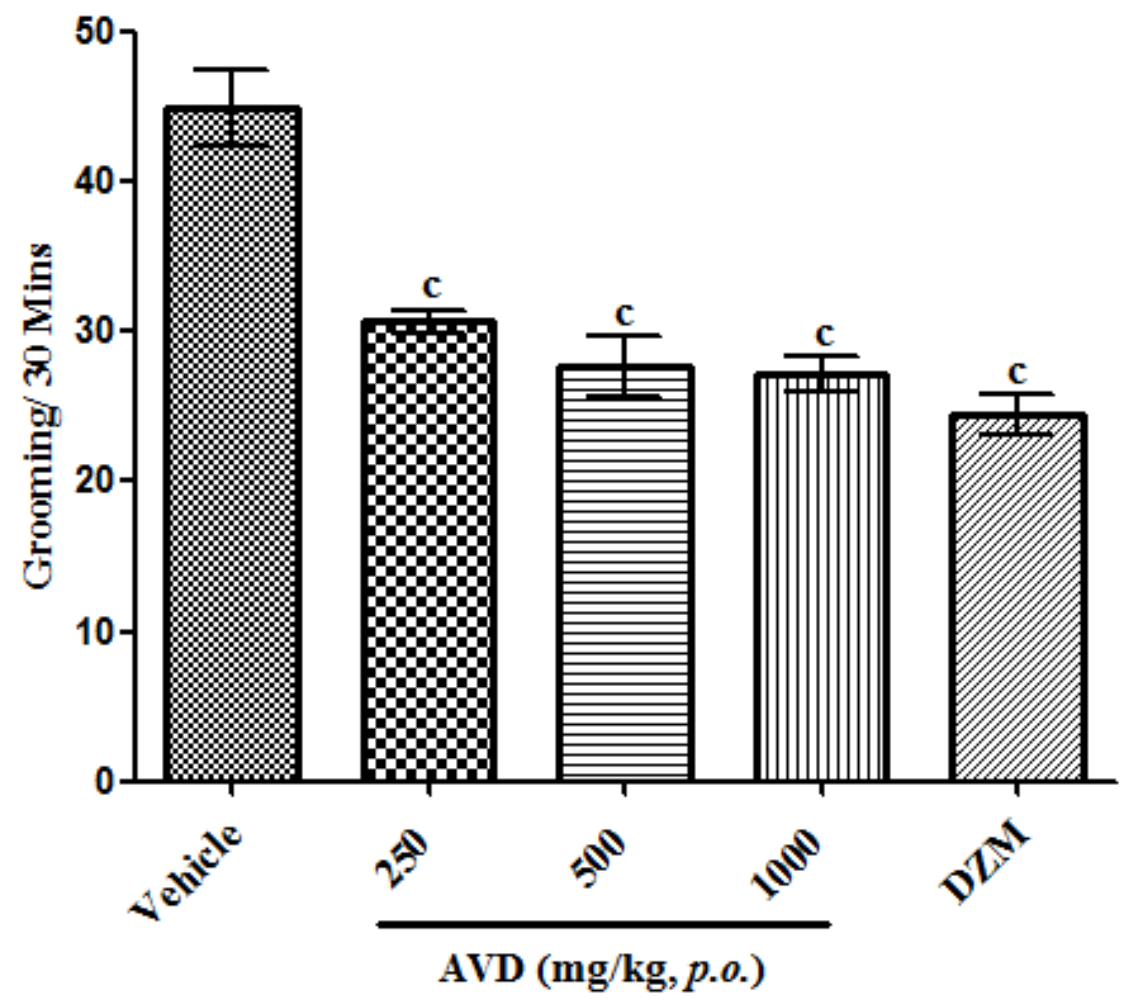

Figure 1c: Effect of aqueous leaf extract of Vitex doniana (AVD) on Grooming in mice. Each bar is expressed as Mean \pm SEM; $(n=6$ per group). $c=P<0.05$ compared to vehicle (normal saline; $10 \mathrm{ml} / \mathrm{kg}$, p.o.); diazepam (DZM) (ANOVA; SNK). 
3.3 Effect of aqueous leaf extract of $V$. doniana on sleep latency in mice

V. doniana at $500 \mathrm{mg} / \mathrm{kg}, 1000 \mathrm{mg} / \mathrm{kg}$ and diazepam $5 \mathrm{mg} / \mathrm{kg}$ showed significant reduction $\left[\mathrm{F}_{4}\right.$, $25=17.73, \mathrm{P}<0.05]$ in latency to sleep, while 250 $\mathrm{mg} / \mathrm{kg}(84.00 \pm 2.70)$ showed no significant reduction to latency to seep compared to vehicle (normal saline) (91.00 \pm 4.60$)$. There was no significant different between $250 \mathrm{mg} / \mathrm{kg}$ and 500 $\mathrm{m} / \mathrm{kg}(73.00 \pm 3.0), 250 \mathrm{mg} / \mathrm{kg}$ and $1000 \mathrm{mg} / \mathrm{kg}$ (72.00 \pm 3.2$)$, nor any between $500 \mathrm{mg} / \mathrm{kg}$ and $1000 \mathrm{mg} / \mathrm{kg}$. The result is presented in Figure $2 a$.

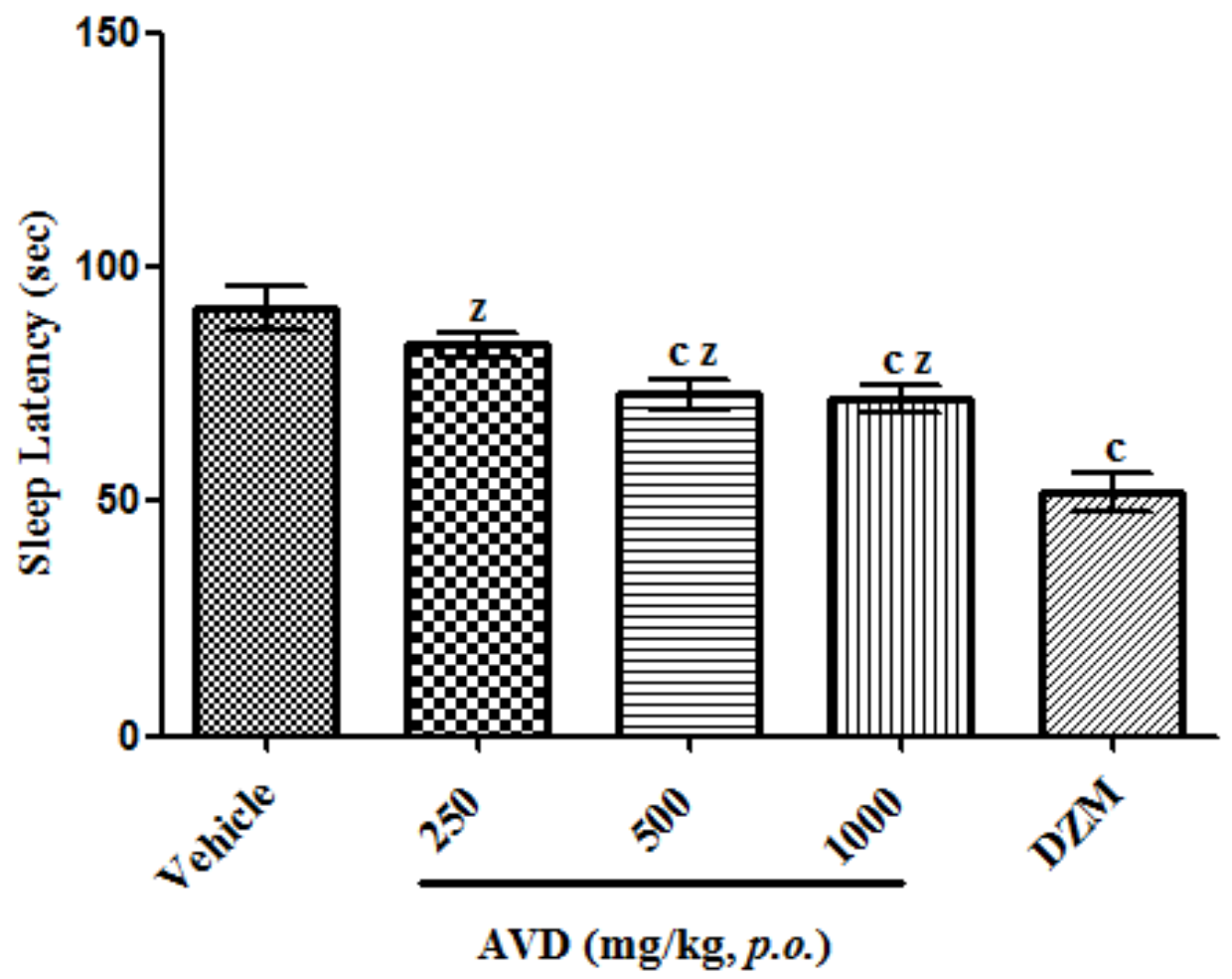

Figure 2a: Effect of aqueous leaf extract of Vitex doniana (AVD) on Sleep Latency in mice. Each bar is expressed as Mean \pm SEM; $(n=6$ per group). $c=P<0.05$ compared to vehicle (Normal saline; 10 $\mathrm{ml} / \mathrm{kg}$, p.o.), and $\mathrm{z}=\mathrm{P}<0.05$ compared to positive control (Diazepam (DZM); $5 \mathrm{mg} / \mathrm{kg}$, p.o.) (ANOVA; SNK).

\subsubsection{Effect of aqueous leaf extract of $V$. do- niana on sleep duration in mice}

V. doniana at $500 \mathrm{mg} / \mathrm{kg}, 1000 \mathrm{mg} / \mathrm{kg}$ and Diazepam $1 \mathrm{mg} / \mathrm{kg}$ showed significant increase $\left[\mathrm{F}_{4,25}\right.$ $=59.90, \mathrm{P}<0.05]$ in sleep duration, while 250 $\mathrm{mg} / \mathrm{kg}(1439.00 \pm 90.00)$ showed no significant increase in duration of sleep compared to vehicle (normal saline) $(1301.00 \pm 35.00)$. There was no significant different between $250 \mathrm{mg} / \mathrm{kg}$ and $500 \mathrm{~m} / \mathrm{kg}(1791.00 \pm 61.00), 250 \mathrm{mg} / \mathrm{kg}$ and $1000 \mathrm{mg} / \mathrm{kg}(72.00 \pm 3.2)$, nor any between 500 $\mathrm{mg} / \mathrm{kg}$ and $1000 \mathrm{mg} / \mathrm{kg}$ (1764.00). The result is presented in Figure $2 \mathrm{~b}$.

3.4 Effect of aqueous leaf extract of $V$. doniana of rectal temperature in mice
There were no significant deviations in the rectal temperature in the control group of animals. Pretreatment with $V$. doniana at $250 \mathrm{mg} / \mathrm{kg}$ showed no significant difference at all the temperature intervals. Hypothermic effect of $V$. doniana was observed at $500 \mathrm{mg} / \mathrm{kg}$ at 60 minutes interval $\left[\mathrm{F}_{4}\right.$, $25=17.21 ; \mathrm{P}<0.05], 1000 \mathrm{mg} / \mathrm{kg}$ at 30 minutes interval $\left[F_{4,25}=17.00 ; P<0.05\right], 60$ minutes interval $\left[F_{4,25}=17.21 ; P<0.05\right], 90$ minutes interval $\left[F_{4,25}=9.63 ; P<0.05\right]$, and 120 minutes interval $\left[\mathrm{F}_{4,25}=29.00 ; \mathrm{P}<0.05\right]$. Pretreatment with 5 $\mathrm{mg} / \mathrm{kg}$ of Diazepam showed significant hypothermic effect at 30 and 60 minutes intervals. The result is presented in Figure $2 \mathrm{c}$. 


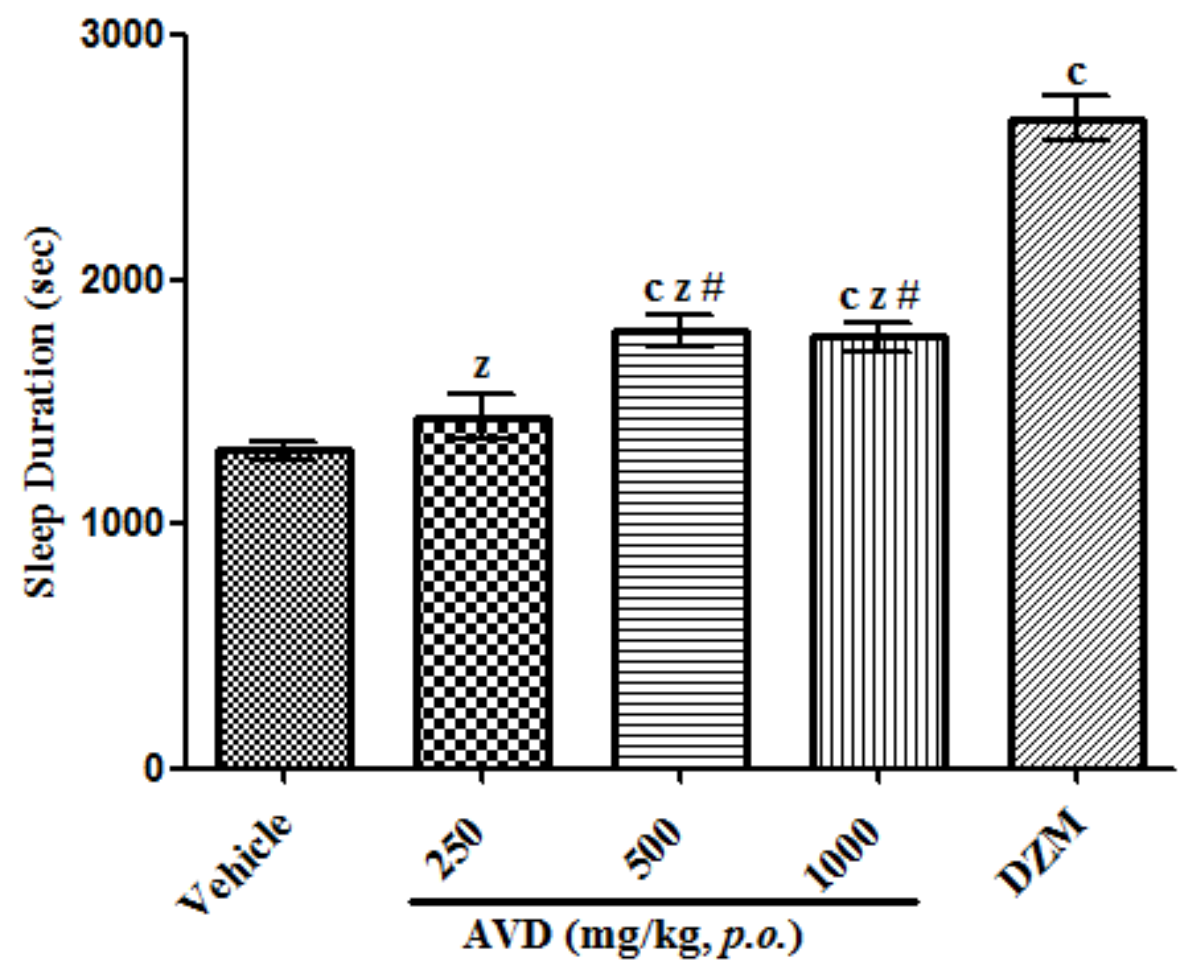

Figure 2b: Effect of aqueous leaf extract of Vitex doniana (VD) on sleep duration in mice. Each bar is expressed as Mean \pm SEM; $(n=6$ per group). $c=P<0.05$ compared to vehicle (Normal saline; 10 $\mathrm{ml} / \mathrm{kg}$, p.o.), and $\mathrm{z}=\mathrm{P}<0.05$ compared to positive control (Diazepam (DZM); $5 \mathrm{mg} / \mathrm{kg}$, p.o.) and \# = $\mathrm{P}<0.05$ compared $250 \mathrm{mg} / \mathrm{kg}$ to $500 \mathrm{mg} / \mathrm{kg}$ and $1000 \mathrm{mg} / \mathrm{kg}$; (ANOVA; SNK).

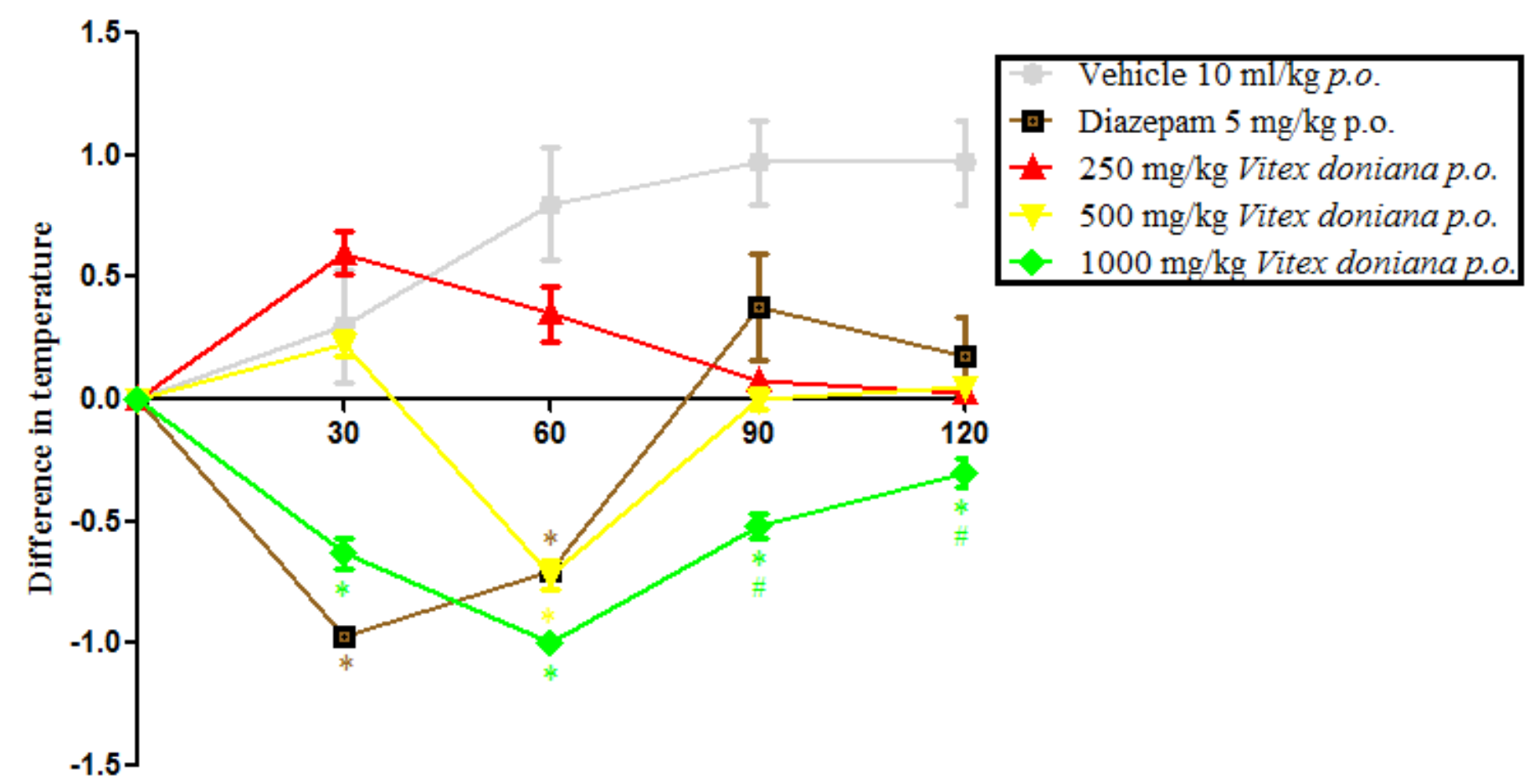

Figure 2c. Effect of aqueous leaf extract of Vitex doniana (VD) on Rectal Temperature in mice. Each graph line is expressed as Mean $\pm S E M$; $\left(n=6\right.$ per group). ${ }^{*}=P<0.05$ compared to vehicle (Normal saline), and \# = $\mathrm{P}<0.05$ compared positive control (Diazepam); (ANOVA; SNK). 


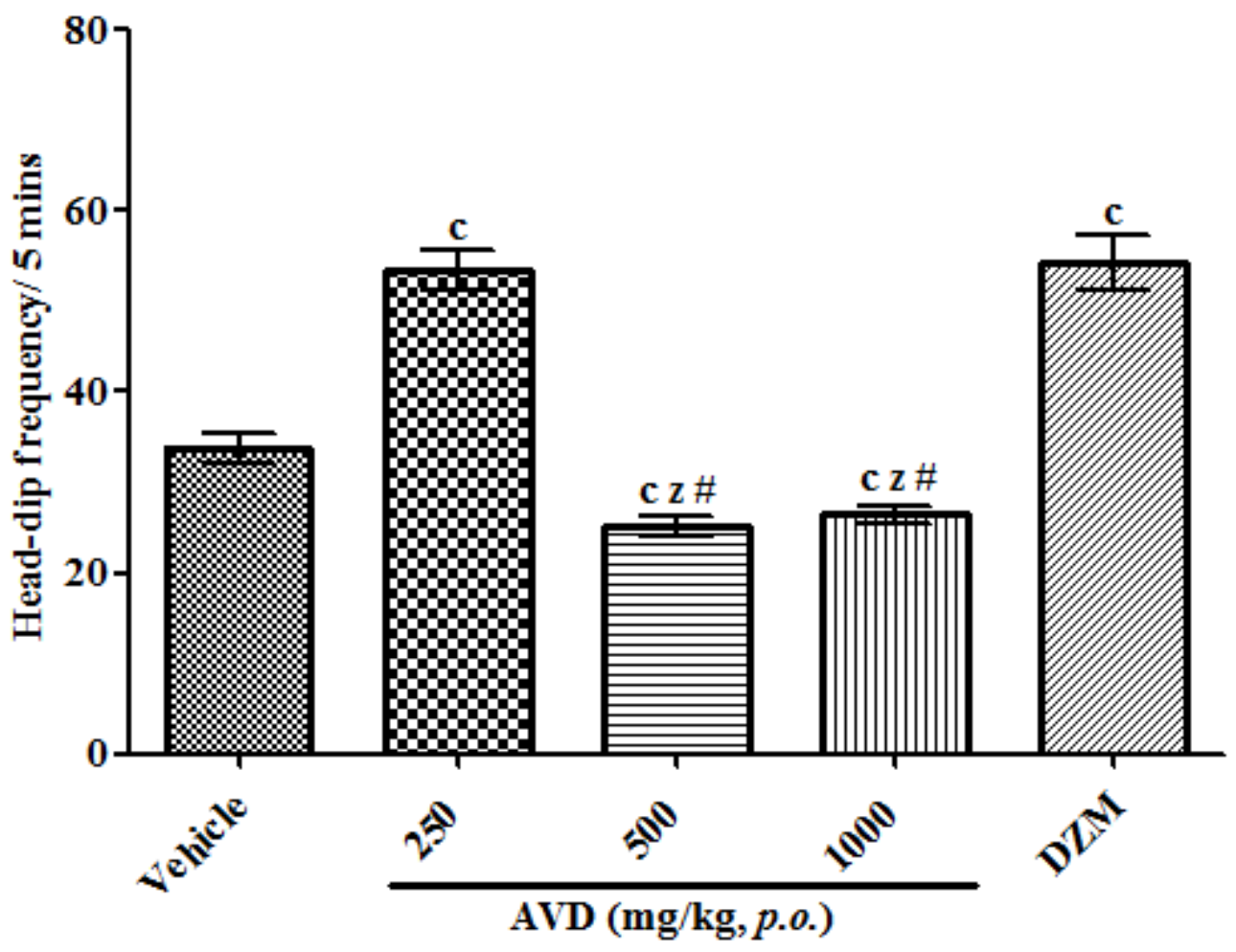

Figure 2d: Effect of aqueous leaf extract of Vitex doniana (AVD) on head-dip frequency in mice. Each bar is expressed as Mean \pm SEM of the head-dip frequency of ice on the hole-board apparatus; ( $n=6$ per group). $c=p<0.05$ compared to vehicle (Normal saline; $10 \mathrm{ml} / \mathrm{kg}, p .0$.), $z=p<0.05$ compared to positive control (Diazepam (DZM); $2 \mathrm{mg} / \mathrm{kg}$, p.o.), and \# $=p<0.05$ compared 250 $\mathrm{mg} / \mathrm{kg}$ to $500 \mathrm{mg} / \mathrm{kg}$ and $1000 \mathrm{mg} / \mathrm{kg}$, (ANOVA; SNK).

\subsection{Effect of aqueous leaf extract of $V$. do- niana on head-dip on hole-board}

The aqueous leaf extract of $V$. doniana at 250 $\mathrm{mg} / \mathrm{kg}$, caused a significant $\left[\mathrm{F}_{4,25}=5500.00\right.$; $\mathrm{P}<0.05]$ increase in the frequency of head-dip compared to the vehicle, $500 \mathrm{mg} / \mathrm{kg}$ and 1000 $\mathrm{mg} / \mathrm{kg}$ of $V$. doniana. Meanwhile, $V$. doniana at the higher doses of $500 \mathrm{mg} / \mathrm{kg}$ and $1000 \mathrm{mg} / \mathrm{kg}$ caused a significant $\left[\mathrm{F}_{4,25}=5500.00 ; \mathrm{P}<0.05\right]$ decrease in the frequency of head-dip on the hole-board apparatus compared to the vehicle, $250 \mathrm{mg} / \mathrm{kg} \mathrm{V}$. doniana and Diazepam $(2 \mathrm{mg} / \mathrm{kg}$; p.o.) There was, however, no significant difference between the $250 \mathrm{mg} / \mathrm{kg}$ of $V$. doniana and Diazepam (2 $\mathrm{mg} / \mathrm{kg}$; p.o.) The result is presented in Figure 2d.

\subsection{Effect of aqueous leaf extract of $V$. do- niana on inhibitory avoidance task}

V. doniana at $250 \mathrm{mg} / \mathrm{kg}$ and diazepam at 2 $\mathrm{mg} / \mathrm{kg}$ caused a significant $\left(\mathrm{F}_{4,25}=226.0\right.$; $\mathrm{P}<0.05)$ decrease in latency to withdrawal from the closed arm of the T-maze. Doses of 500 $\mathrm{mg} / \mathrm{kg}, 1000 \mathrm{mg} / \mathrm{kg}$ of $V$. doniana and vehicle groups showed significant $\left(F_{4}, 25=226.0\right.$; $\mathrm{P}<0.05)$ increase in latency to withdrawal from the closed arm of the T-maze compared to the Diazepam and $250 \mathrm{mg} / \mathrm{kg}$ groups. However, there was no significant difference in the baseline latency, that is, the first time to withdraw from the closed arm $\left(A_{1}\right)$ in all the treatment groups (including the diazepam group) compared to the vehicle. The result is presented in Figure 2e.

\subsection{Effect of aqueous leaf extract of $V$. do- niana on one-way escape task}

$V$. doniana at all doses tested caused a significant $\left[F_{4,25}=23.19 ; P<0.05\right]$ increase in latency to withdrawal from the open arm of the T-maze compared to the vehicle (normal saline). The dose of $2 \mathrm{mg} / \mathrm{kg}$, p.o. diazepam also caused a significant increase in the latency to withdrawal from the open arm compared to the vehicle. 
There was also no significant difference among to withdrawal from the open arm of the T-maze. all the treatment groups in baseline latency $\left(E_{1}\right) \quad$ The result is presented in Figure $2 \mathrm{e}$.

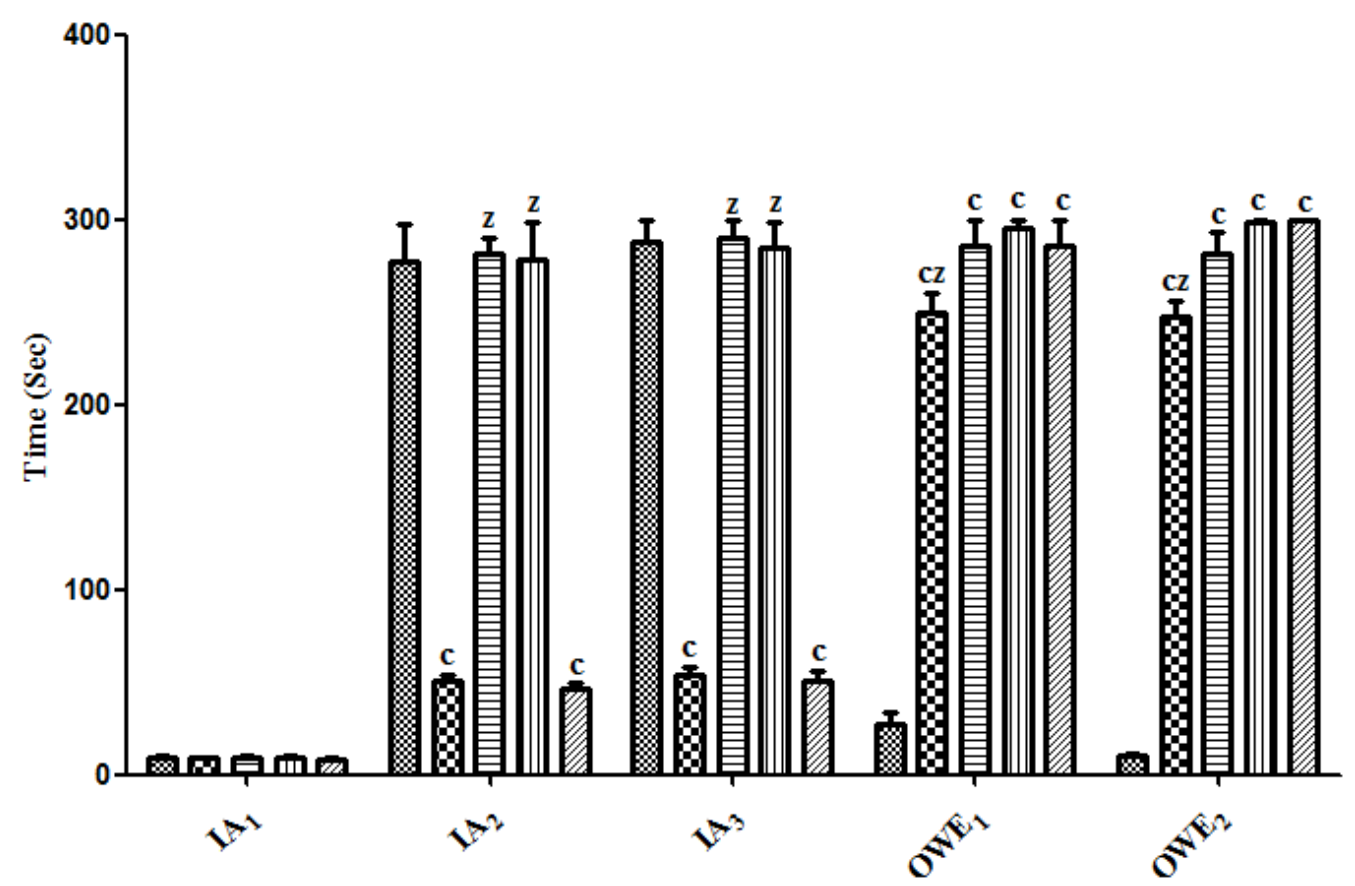

Figure 2e: Effect of aqueous leaf extract of Vitex doniana (AVD) on Inhibitory Avoidance (IA; baseline) and One-Way Escape (OWE) on T-maze in mice. Each bar is expressed as Mean \pm SEM of time (Sec) spent in the opened and closed arms of the maze by mice; ( $n=6$ per group). $c=P=.05$ compared to vehicle (Normal saline), and $z=P=.05$ compared to positive control (Diazepam), (ANOVA; SNK).

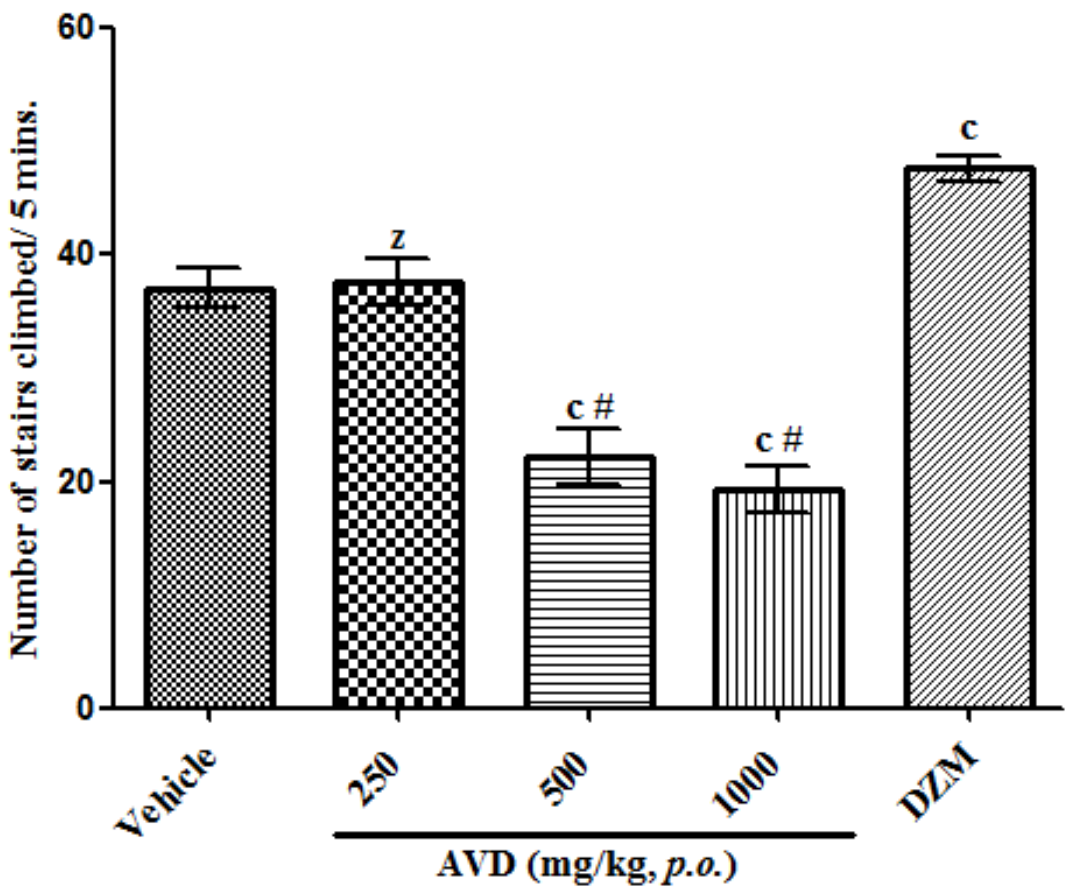

Figure 2f: Effect of aqueous leaf extract of Vitex doniana (AVD) on stairs climbing in mice. Each bar is expressed as Mean \pm SEM of the number of stairs climbed by mice; ( $n=6$ per group). $c=P<0.05$ compared to vehicle (Normal saline; $10 \mathrm{ml} / \mathrm{kg}$, p.o.), $\mathrm{z}=\mathrm{P}<0.05$ compared to positive control (Diazepam (DZM); $2 \mathrm{mg} / \mathrm{kg}$, p.o.), and \# = P<0.05 compared to compared $250 \mathrm{mg} / \mathrm{kg}$ to $500 \mathrm{mg} / \mathrm{kg}$ and $1000 \mathrm{mg} / \mathrm{kg}$, (ANOVA; SNK). 
3.8 Effect of $V$. doniana on the number of steps climbed

$V$. doniana at $250 \mathrm{mg} / \mathrm{kg}$ caused non-significant increase $(38.00 \pm 2.0)$ in the number of steps climbed compared to the vehicle group (37.00 \pm 1.7). V. doniana at both 500 and $1000 \mathrm{mg} / \mathrm{kg}$ showed significant reduction $\left[\mathrm{F}_{4,25}=38.86\right.$; $\mathrm{P}<0.05]$ in the number of steps climbed compared to both vehicle and diazepam. The result is presented in Figure $2 \mathrm{f}$.
$V$. doniana in all the doses tested in this study, and diazepam (2 mg/kg, p.o.) showed significant difference $\left[F_{4,25}=46.88 ; P<0.05\right]$ in the number of rearing on the staircase compared to the vehicle. 500 and $1000 \mathrm{mg} / \mathrm{kg}$ of $V$. doniana showed a significant difference compared to $250 \mathrm{mg} / \mathrm{kg}$ $V$. doniana. There was, however, no significant difference between $500 \mathrm{mg} / \mathrm{kg}$ of $V$. doniana compared to $1000 \mathrm{mg} / \mathrm{kg}$. The result is presented in Figure $2 \mathrm{~g}$.

\subsection{Effect of $V$. doniana on the number of numbers of rearing}

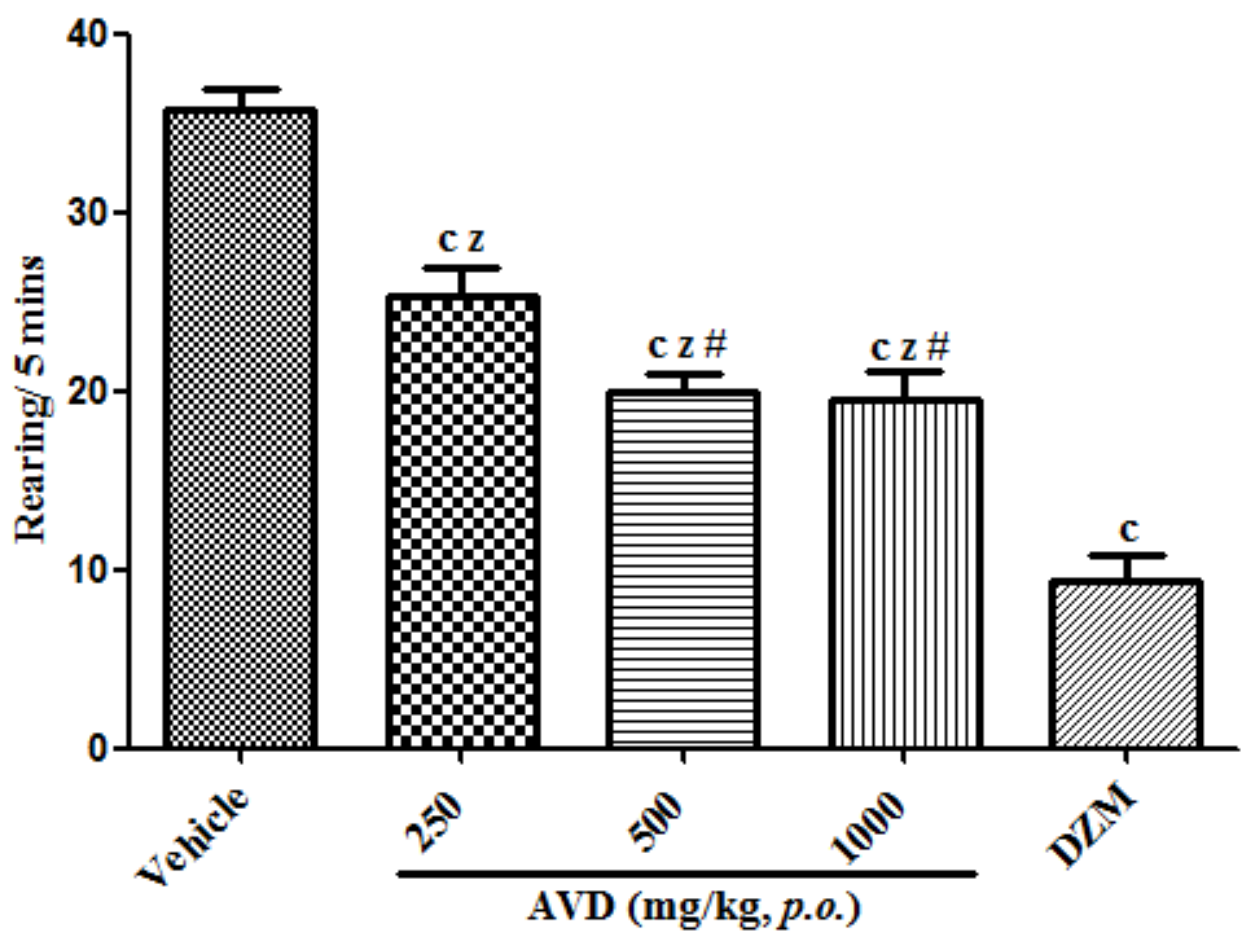

Figure 2g: Effect of aqueous leaf extract of Vitex doniana (AVD) on rearing on stairs in mice. Each bar is expressed as Mean \pm SEM of the number of rearing on stairs by mice; $(n=6)$. $c=P<0.05$ compared to Vehicle (Normal saline, $10 \mathrm{ml} / \mathrm{kg}$, p.o.), $\mathrm{z}=\mathrm{P}<0.05$ compared to positive control (Diazepam (DZM); $2 \mathrm{mg} / \mathrm{kg}$, p.o.) and \# = P<0.05 compared to compared $250 \mathrm{mg} / \mathrm{kg}$ to $500 \mathrm{mg} / \mathrm{kg}$ and $1000 \mathrm{mg} / \mathrm{kg}$, (ANOVA; SNK).

\subsection{Rapid Radical Scavenging Property of Aqueous Leaf Extract of $V$. doniana}

The extract upon TLC development in butanolacetic acid-water (BAW) 80:15:5 solvent system and sprayed with DPPH radical solution showed some strong free radical scavenging spots, which appeared yellow or bleached the purple DPPH background. The reaction was time-dependent as some spot reacted immediately (strongly antioxidant), some reacted after 5 minutes, 30 minutes and 24 hours of spray, as indicated in Table 2.

\section{DISCUSSION}

This study investigated the acute toxicity profile, anxiolytic, sedative effects and the rapid radical scavenging properties of the aqueous leaf extract of Vitex doniana (AVD) in mice models. 
The AVD was found not to yield any toxicity, nor did it produce any varied symptoms of deferred toxicity in terms of atypical behaviours in mice when administered orally up to $5000 \mathrm{mg} / \mathrm{kg}$ body weight according to Lorke's method of acute toxicity testing [21]. Intraperitoneally, however, the AVD was found to have a median lethal dose $\left(L D_{50}\right)$ of $894 \mathrm{mg} / \mathrm{kg}$, i.p. in mice. Thus, it can be inferred that $A V D$, based on general categorizations of a toxic compound, is safe in mice when administered through the oral route ${ }^{[41]}$. The AVD can be said to be moderately toxic to the experimental animal model (mice) used in this study when administered intraperitoneally. Lorke [21], stated that substances toxic at less than $1 \mathrm{mg} / \mathrm{kg}$ are considered to be highly toxic; and considering that the $\mathrm{LD}_{50}$ estimate of this plant extract was far above this toxicity level thus, AVD can be said to be moderately toxic intraperitoneally. Also, Vernonia amygdalina with a similar $\mathrm{LD}_{50}$ of $894 \mathrm{mg} / \mathrm{kg}$ i.p., has been adjudged to be moderately toxic ${ }^{[42]}$.

Table 2: TLC-Bioautography for the DPPH Radical Scavenging Property of Aqueous Leaf Extract of $V$. doniana

\begin{tabular}{|c|c|c|c|c|}
\hline Solvent System & TLC Chromatogram & $\begin{array}{l}\text { Retardation } \\
\text { factor }\left(\mathbf{R}_{\mathrm{f}}\right)\end{array}$ & $\begin{array}{l}\text { DPPH Radical Scav- } \\
\text { enging Property }\end{array}$ & $\begin{array}{l}\text { Suspected Secondary } \\
\text { metabolite }\end{array}$ \\
\hline \multirow{9}{*}{$\begin{array}{l}n \text {-butanol }- \text { acetic } \\
\text { acid - distilled water } \\
\text { (BAW) 80:15:5 }\end{array}$} & Spot 1 & 0.96 & +++ & fatty acid ester \\
\hline & Spot 2 & 0.93 & +++ & fatty acid ester \\
\hline & Spot 3 & 0.75 & + & terpene \\
\hline & Spot 4 & 0.61 & $+/-$ & terpene \\
\hline & Spot 5 & 0.55 & $+/-$ & terpene \\
\hline & Spot 6 & 0.48 & + & terpene \\
\hline & Spot 7 & 0.33 & ++ & phenolic compound \\
\hline & Spot 8 & $0.27-0.15$ & +++ & $\begin{array}{l}\text { phenolics / phenolic gly- } \\
\text { coside }\end{array}$ \\
\hline & Spot 9 & $0.10-0.01$ & +++ & $\begin{array}{l}\text { phenolics and phenolic } \\
\text { glycoside }\end{array}$ \\
\hline
\end{tabular}

Key: +++ very strong (immediate reaction), ++ strong (after 5 minutes), + weak (after 30 minutes), +/- trace (after 24 hrs.), TLC- thin-layer chromatography, DPPH- 2,2-diphenyl-1-picrylhydrazyl radical.

The study revealed that oral administration of AVD significantly reduced locomotion, rearing and grooming of mice when compared to the control in the open field test. Locomotion, rearing and grooming are central excitatory locomotor behaviour associated with motivational state and arousal level and are regarded as 'arousal' or 'stress' phenomenon [43,44], and decrease in these index of alertness indicates an inhibitory effect ${ }^{[45-47]}$. In this study, it was observed that AVD produced a decrease in locomotion, rearing and grooming in the open field test indicating a CNS inhibitory activity. This effect is comparable to that of diazepam (a sedative drug), which also reduced rearing and locomotion significantly compared to normal saline (control). The observed effect might be due to AVD acting via the blockade of dopamine, potentiation of GABA, inhibition of serotonin, inhibition of cholinergic neurotransmission and inhibition of the stimulation of the excitatory neurotransmitter in the CNS [48,49].

This study showed AVD to have significant anxiolytic effect at the lower dose of $250 \mathrm{mg} / \mathrm{kg}$, and significant sedative effect at the higher doses of $500 \mathrm{mg} / \mathrm{kg}$ and $1000 \mathrm{mg} / \mathrm{kg}$. These were

IJTCM: https://escipub.com/international-journal-of-traditional-and-complementary-medicine/ 14 
evidenced in all the models of anxiety and sedation used in this study. AVD at $250 \mathrm{mg} / \mathrm{kg}$ showed a significant increase in the frequency of head- dips on the hole- board apparatus, significantly reduced the latency to inhibitory avoidance (withdrawal from the closed arm), while significantly increased the latency to one- way escape (withdrawal from the open arm), and on the staircase model, AVD at $250 \mathrm{mg} / \mathrm{kg}$ non-significantly increase the number of stairs climbed, while significantly decrease rearing on the staircase. Anxiolytics, on the hole- board - a model that various reports have shown can be used for evaluation of anxiety condition in experimental animals - will cause an increase in the frequency of head- dips [30,42,50-54]. Also, anxiolytics have been reported to cause a reduction in inhibitory avoidance and increase in latency to one- way escape ${ }^{[42,55,56]}$. The reported reduction in rearing at a dose(s) which did not reduce the number of steps climbed on the staircase was a feature of anxiolytic activity [57]. A significant increase in numbers of steps climbed with a decrease in rearing is also reported to be a feature of both anxiolytic and sedative effects [58]. However, reduction in both rearing and climbing behaviours on the staircase model has been adjudged as features of both anxiolytic and sedative effects [28,29],

The aqueous leaf extract of $V$. doniana at both $500 \mathrm{mg} / \mathrm{kg}$ and $1000 \mathrm{mg} / \mathrm{kg}$ showed a sedative effect on the hole- board elevated T-maze, and staircase models. The number of head- dips were significantly reduced, there was a concurrent significant increase in latency to both inhibitory avoidance and one- way escape, and both the number of staircases climbed and rearing were significantly reduced. Numerous reports have opined, that these said observations are features of sedative activities [28,29,42,50,57,58]. The sedative effect of AVD at $500 \mathrm{mg} / \mathrm{kg}$ and 1000 $\mathrm{mg} / \mathrm{kg}$ was further revealed in the ketamine-induced sleeping time and rectal temperature models. The use of ketamine-induced sleeping time in laboratory animals, for the evaluation of the sedative activity of agents, is commonly well accepted [37,59]. AVD showed sedative activity at the said doses, by significantly reducing the sleep latency, and significantly increasing the sleep duration. Meanwhile, sedation, muscle relaxation and hypothermia are thought to be closely linked or related, as previous studies have shown that agents with significant CNS inhibition exhibited these effects [38,60-62]. AVD at $500 \mathrm{mg} / \mathrm{kg}$ and $1000 \mathrm{mg} / \mathrm{kg}$ doses tested in this study showed hypothermia in mice at different intervals thereby reinforcing its sedative effect.

The TLC bioautography revealed the rapid radical scavenging property of the plant extract and their corresponding class of secondary metabolites. Among the strong free radical scavengers suspected in the plant extract were fatty acid esters, phenolics and phenolic glycoside. These phytochemicals have been reported to be responsible for many neuro- and psychopharmacology effects observed in different plant extracts ${ }^{[63-69]}$. Therefore, the sedative, hypothermic and anxiolytic effects of the aqueous extract of $V$. doniana could be due to the presence of the afore-mentioned free radical scavenging group of compounds, which may be centrally acting through the modulation of the glycine, GABA, dopamine and serotonin receptors systems.

It can be concluded that the aqueous leaf extract of $V$. doniana possesses significant sedative, hypothermic and anxiolytic effects, which could in part be due to the presence of rapid free radical scavenging compounds, thus, providing pharmacological justification for its ethnomedicinal uses as a curative for madness, insanity and epilepsy in Nigeria and some other African countries. The extract is safe in oral administration, but moderately toxic in intraperitoneal administration in mice.

\section{Acknowledgements}

The authors wish to appreciate the technical staff of the Laboratory Unit of the Department of Pharmacology, Faculty of Pharmacy, Obafemi Awolowo University lle-lfe, Nigeria, for their necessary laboratory assistance during the laboratory work of this study.

IJTCM: https://escipub.com/international-journal-of-traditional-and-complementary-medicine/ 


\section{Competing interests}

We declare that no competing interests exist.

\section{Funding}

This research did not receive any specific grant from funding agencies in the public, commercial, or not-for-profit sectors.

\section{Authors' Contributions}

This work emanated from the PhD research works of JOI. JOI conceived and designed the study, performed and managed the literature search, statistical analysis, carried out the laboratory works and wrote the first draft of the manuscript. AOO carried out the phytochemical work and wrote part of the manuscript. MAA supervised, and provided some materials used in the work, while IAO co-supervised the work, provided some materials used in the work and also assisted in some of the laboratory works. All authors read and approved the final manuscript.

\section{References}

1. Orwa C, Mutua A, Kindt R, Jamnadass R, Anthony S. Agroforestree Database:a tree reference and selection guide version 4.0. World Agroforestry Web site. 2009.

2. Ky KJM. Vitex doniana Sweet [Internet]. PROTA4U. 2008 [cited 2018 Nov 7]. Available from: http://www.prota4u.org/search.asp.

3. Iwu MM. Handbook of African Medicinal Plants. London: CRC; 1993.

4. Ladeji O, Udo F, Okoye Z. Activity of aqueous extract of the bark of Vitex doniana on some uterine response to drugs. Phyther Res. 2004;19:804-6.

5. Bethesda MD. Stem cell Markers in Stem cell information. J Dent Res. 2009;65(2):125-7.

6. Erhenhi E, Obadoni BO. Known medicinal and aphrodisiac plants of Urhonigbe forest reserve, Edo State, Nigeria. J Med Plants Stud. 2015;3(4):101-6.

7. Vunchi MA, Umar AN, King MA, Liman AA, Jeremiah G, Aigbe CO. Proximate, Vitamins and Mineral Composition of Vitex doniana (black plum) Fruit Pulp. Niger J Basic Appl Sci. 2011;19(1):98-101.

8. Olujobi OJ. Evaluation of the nutritive composition of five indegenous tree leaves used as vegetable in Ekiti State. J Agric Enviromental Sci. 2015;4(1):18597.

9. Dawang ND. Phytochemical Constituents and Toxicological Study of Vitex Doniana Leaf. 2015;10(5):23-7.
10. Iloh EO, Onyema IB, Agbafor KN, Ezeilo RU. Preliminary Phytochemical and Antimicrobial Screening of Vitex doniana Leaves. J Med Dent Sci. 2015;2(10):10-2.

11. Kuta FA, Onochie I, Garba S, Adedeji AS. An invitro and in-vivo antibacterial activity of Vitex doniana crude extracts on Salmonella typi. Int J Sci Res Sci Eng Technol. 2015;1(5):71-9.

12. Aiwonegbe AE, lyasele JU, Momodebe RO. Characterization of a natural dye produced from the alcoholic extract of African black plum (Vitex doniana) fruit pulp using wool fabric. In: Material Science and Technology Society of Nigeria (MSN). 2017. p. 1059.

13. Abdulrahman, I F, Akan, C J, Sodipo, A O, et al. Effect of Aqueous Root-Bark Extract of Vitex Doniana Sweet on Haematological Parameters in Rats. J Am Sci [Internet]. 2010;6(12):8-12. Available from: http://www.americanscience.org

14. Iwueke A, Nwodo O, Okoli C. Evaluation of the anti-inflammatory and analgesic activities of Vitex doniana leaves. African J Biotechnol. 2006;5(20):1929-35.

15. Agbafor K, Nwachukwu N. Phytochemical Analysis and Antioxidant Property of Leaf Extracts of Vitex doniana and Mucuna pruriens. Biochem Res Int. 2011;1-4.

16. Agunu A, Yusuf S, Andrew GO, Zezi AU, Abdulrahman EM. Evaluation of five medicinal plants used in diarrhoea tratment in Nigeria. $\mathrm{J}$ Ethnopharmacol. 2005;101(1-3):27-30.

17. Nwogo AO, Kalu MK, Godwin CC, Glory O, Nweke CN. Effects of Aqueous and Methanolic Leaf Extracts of Vitex doniana on Lipid Peofile and Liver Enzymes of Alloxan Induced Diabetic Albino Rats. IOSR J Pharm Biol Sci. 2013;6(5):36-43.

18. Nwaneri-Chidozie V, Yakubu O, Jatto O, Paul PL. Lipid Profile Status of Streptozotocin-induced Diabetic Rats Treated with Ethanol, N-Hexane and Aqueous Extracts of Vitex doniana Leaves. Res J Pharm Biol Chem Sci. 2014;5(2):40-9.

19. Yadav A, Kawale L, Nade V. Effects of Morus alba $\mathrm{L}$. (Mulberry) leaves on anxiety in mice. Indian $\mathrm{J}$ Pharmacol. 2008;40:32-6.

20. Lal H, Emmet-Oglesby MW. Behavioural analogus of anxiety: Animal models. Neuropharmacology. 1983;22(12b):1423-41.

21. Lorke D. A new approach to practical acute toxicity testing. Arch Toxicol. 1983;54:275-87.

22. Ajayi AA, Ukponmwan OE. Positive evidence of angiotensin and endogenou opiod modulation of anxiety-induced rearing in rats. African $\mathrm{J}$ Med Sci. 1994;22:287-90.

IJTCM: https://escipub.com/international-journal-of-traditional-and-complementary-medicine/ 
Joshua Oloruntobi IMORU et al., IJTCM, 2020, 5:32

23. Brocco M, Dekeyne A, Viegn S, Girardon S, Millan MJ. Induction of hyperlocomotion in mice exposed to a novel enviroment by inhibition of serotonin reuptake: a pharmacological characterization of diverse classes of antidepressant agents. Pharmacol Biochem Behav. 2002;77:667-80.

24. Brown AG, Corey S, Moore AK. Difference in measures of exploration and fear in MHC-Congenic C57 BL/6J and B6-H-2K mice. Behav Genet. 1999;26:263-71.

25. Brown RG, Nemes C. The exploratory behaviour of rats in the hole-board apparatus: is head-dipping a valid measure of neophilia? Behavoural Process. 2008;78(3):442-8.

26. Graeff FG, Viana MB, Tomaz C. The elevated Tmaze a new experimental model of anxiety and memory: Effect of diazepam. Brazillian J Med Biol Res. 1993;16:69-70.

27. Simiand J, Keane PE, Moore M. The staircase test in mice: a simple and procedure for screening of anxiolytic agents. J Psychopharmacol. 1984;84:4853.

28. Pandiamunian J, Lavakumar S, Pandian J, Somasundaram G, Sabash KR. Evaluation of anxiolytic effect of pet- ether extract of Portala caoleracea (Linn.) in mice. Int J Appl Bbiology Pharm Technol. 2012;3:209-14.

29. Magaji MG, Yaro AH, Musa AM, Anuka JA, AbduAgaye I, Hussaini IM. Sadative activity of residual aqueous fraction of Securinega virosa (roxbrex wild) baill. root bark extract in mice. Niger J Pharm Sci. 2011;10(2):34-44.

30. Casarrubea M, Filippina S, Santageb A, Crescimanno G. Microstructural Assessment of Rodent Behaviour in Hole- board. In: Spink AJ, Grieco F, Krips OE, Loijens LWS, Noldus LPJJ, Zimmerman $\mathrm{PH}$, editors. Experimental Assay, Proceedings of Measuring Behavoir. Nertherlands: Eindhoven; 2010. p. 133-6.

31. Vogel HG. Drug Discovery and Evaluation: Pharmacological Assays. 2nd ed. Berlin: Heidelberg, NY, Springer-Verlay; 2002.

32. Oyemitan IA, Elusiyan CA, Akanmu MA, Olugbade TA. Hypnotic, anticonvulsant and anxiolytic effects of 1-nitro-2-phenylehane isolated from the essentia oil of Dennettia tripetala in mice. Phytomedicine. 2013;1-8.

33. Oyemitan IA, Ojo E, Oyedeji AO. Neuropharmacological profile of ethanolic dried extract seed of Persea americana in mice. African $\mathrm{J}$ Pharm Pharmacol. 2016;10(22):480-92.

34. Siqueira I, Lara D, Silva D, Gaieski F, Nunes D, Elisabetsky E. Psychopharmacological properties of
Ptochopetalum olacoides Bentham (Olacaeae). Pharm Biol. 1998;36(5):327-34.

35. Dandiya RC, Collumbine H. Studies on Acorus calamus III. Some Pharmacological actions of the volatile oil. J Ethnopharmacol Exp Ther. 1999;125:353-9.

36. Hellion-Ibarrola MC, Ibarrola DA, Montalbetti $Y$, Villalba D, Helinichen O, Ferro EA. Acute toxicity and general pharmacological effect on central nervous system of crude rhizome extract of Kyllinga brevifola Rottb. J Ethnopharmacol. 1999;66:272-6.

37. Ayoka AE, Akomolafe RO, Iwalewa EO, Akanmu MA, Ukponmwan OE. Sedative, anti- epileptic and antipsychotic effects of Spondias mombin L. (Anacardiaceae) in mice and rats. J Ethnopharmacol. 2006;103:166-75.

38. Oyemitan IA, Iwalewa EO, Akanmu MA, Olugbade TA. Sedative, Hypothermic, and Muscle Relaxant effects of the Essential oils of Dennettia tripetala G. Baker (Annonaceae), and its mechanisms in Mice. Ife J Sci. 2008;10(1):1-9.

39. Burits M, Bucar F. Antioxidant activity of Nigella sativa essential oil. Phyther Res. 2000;14:323-8.

40. Mensor LL, Fábio SM, Gilda GL, Alexandre SR, Tereza C dos S, Cintia SC, et al. Screening of Brazilian plant extracts for antioxidant activity by the use of DPPH free radical method. Phyther Res. 2001;15:127-130.

41. Alhaddad H, Fadhil AM, Ismael SH. Estimation of LD50 and Toxicity of Zygophyllum fabago in Mice. Am J Pharmacol Sci. 2015;3(4):94-7.

42. Imoru JO, Oyemitan IA, Ilesanmi OR. Anxiolytic, Sedative and Hypothermic Effects of Aqueous Leaf Extract of Vernonia amygdalina Del (Asteraceae) in Albino Mice. $\mathrm{Br} J$ Pharmacutical Res. 2014;4(8):2210-25.

43. Dourish CT, Cooper SJ. Neural basis of druginduced yawning. In: Cooper SJ, Dourish CT, editors. Neurobiology of stereotyped behaviour. Oxford: Oxford University Press; 1990. p. 91-116.

44. Sadile AG. Long- time habituation of theta-related activity components of albino rats in the Latmaze. In: Sanberg PP, Ossenkopp KP, Kavaliers M, editors. Motor activity and movement disorders: measurement and analysis. New York: Humuna Press; 1995. p. 154.

45. Thakur VD, Mengi SA. Neuropharmacology Profile of Eclipta alba (Linn) Hassk. J Ethnopharmacol. 2005;102:23-31.

46. Aderibigbe AO, Adeyemi IO, Agboola OI. Central Nervous System Depressant Properties of Treculia africana Decne. Ethnopharmacol Leafl. 2010;14:108. 
47. Akanmu MA, Olowookere TA, Atunwa SA, Ibrahim BO, Lamidi OF, Adams PA, et al. Neuropharmacological Effects of Nigerian Honey In Mice. African J Tradit Complement annd Altern Med. 2011;8(3):230-49.

48. Jones D., Mongenson GJ, Wu M. Injection of dopaminergic, cholinergic, serotonergic and GABAergic drugs into the nucleous accubens effect on locomotor activity in rats. Neuropharmacology. 1981;20:29-37.

49. Strange PG, Neve K. Dopamine Receptors [Internet]. Tocris Bioscience Scientific Review Series. 2013 [cited 2019 Apr 22]. Available from: https://resources.tocris.com/pdfs/archive/pdf_downlo ads/dopamine_receptors_review.pdf

50. File SE, Wardill AG. Validity of head-dipping as ameasure of exploration in a modified hole- board. Psychopharmacology (Berl). 1975;44:53-9.

51. Pellow S, Chopin P, File SE, Briley M. Validation of open: closed arm entries in an elevated plus-maze as a measure of anxiety in the rat. $\mathrm{J}$ Neurosci Methods. 1985;14(3):149-67.

52. Takeda H, Tsuji M, Matsumiya T. Changes in head- dipping behaviour in hole- board test reflected the anxiogenic and/or anxiolytic state in mice. Eur $\mathrm{J}$ Pharmacol. 1998;350(1):21-9.

53. Kishore RN, Anjaneyulu N, Ganesh MN, Sravya $\mathrm{N}$. Evaluation of anxiolytic activity of ethanolic extract of Foeniculum vulgare in mice model. Int $\mathrm{J}$ Pharm Pharm Sci. 2010;4(3):584-5.

54. Barua CC, Begum SA, Barua AG, Borah RS, Lahkar M. Anxiolytic and anticonvulsant activity of methanol exttract of leaves of Alteranthera brasiliana in laboratory animals. J Exp Biol. 2013;51:450-7.

55. Teixeria RC, Zangross-Jr H, Graeff FG. Behavioural effects of acute and chronic imipramine in the elevated T- maze model of anxiety. Pharmacol Biochem Behav. 2000;65:571-6.

56. Pinheiro, S.H, Zangrossi-Jr H, Del-Ben CM, Graeff FG. Elevated mazes as animal models of anxiety: effeccts of serotonergic agents. Ann da Acad Bras Ciencias (Annals Brazilian Acad Sci. 2007;79(1):71-85.

57. Bhaltacharya SK, Satyan KS. Experimental methods for evaluation of psychotropic agents in rodents: I - Antianxiety agents. Indian J Exp Biol. 1997;33:565-75.

58. Patel NB, Kumar S, Prasad AK, Patel JA, Patel HA. Assessment of anxiolytic activityof aqueous extract of magnifera indica $L$. leaves in rodents exposed to chronic unpredictable mild stress. Int Res J Pharm. 2013;4(1):247-51.

59. Singh N, Kaur S, Bedi PMS, Kaur D. Anxiolytic

IJTCM: https://escipub.com/international-journal-of-traditional-and-complementary-medicine/ effects of Equisetum arvense Linn. extract in mice. Indian J Exp Biol. 2011;49:352-6.

60. Asusu U, Ezejiofor S, Njoku CJ. The pharmacological activities of Olax viridis root bark on central nervous system. Fitoterapia. 1998;69:260-4.

61. Vale TG, Matos FJA, De-Lima TCM, Viana GSB. Behavioural effects of essential oils from Lippia alba (Mill) N.E. Brown chemotypes. J Ethnopharmacol. 1999;167:127-33.

62. Hague S, Choudhuri MSK, Islam MV, Hannan JMA, Shahriar M. Pharmacological study of Sri Mahalaxmi bilas (Rasayan). Hamhard Med. 2001;44:54-60.

63. Houghton PJ. The scientific basis for the reputed activity of valerian. J Pharm Pharmacol. 1999;51:50512.

64. Dhawan K, Kumar, Sharma A. Anti-anxiety studies on extracts of passiflora incarnate Linneaus. J Ethnopharmacol. 2001;78:165-70.

65. Carlini EA. Plants and the central nervous system. Pharmacol Biochem Behav. 2003;75:510-2.

66. Akindele AJ, Adeyemi OO. Anxiolytic and Sedative effects of Byrsocarpus coccineus Schum. and Thonn. (Connaraceae) extract. Int J Appl Res Nat Prod. 2010;3(1):28-36.

67. Gupta G, Kazmi K, Afzal M, Rhaman M, Saleem $S$, Ashraf MS, et al. Sedative, antiepileptic, and antipsychotic effects of Viscum album L. J Ethnopharmacol. 2012;141:810-6.

68. Lozada-Lechuga J, Villarreal ML, Fliniaux MA, Bensaddek L, Mesnard F, Gutiérrez MC, et al. Isolation of jacaranone, a sedative constituent extracted from the flowers of the Mexican tree Ternstroemia pringlei. J Ethnopharmacol. 2010;127(2):551-4.

69. Nugroho A, Lim SC, Choi J, Park HJ. Identification and quantification of the sedative and anticonvulsant flavone glycoside from Chrysanthemum boreale. Arch Pharm Res. 2013;36(1):51-60.

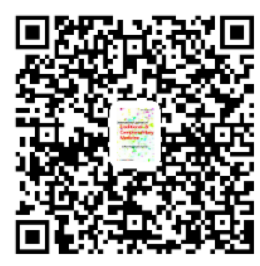

